
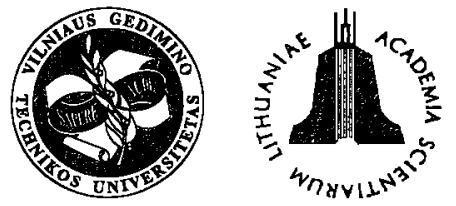

ISSN 1648-4142 TRANSPORT

http:/www.vtu.lt/english/editions

TRANSPORT - 2003, Vol XVIII, No 2, 79-83

\title{
TRAFFIC SAFETY STRATEGIES
}

\author{
Vigilijus Sadauskas \\ Dept of Automobile Transport, Vilnius Gediminas Technical University, J. Basanavičiaus g. 28, \\ LT-2009Vilnius,_Lithuania.E-mail: v.sadauskas@transp.lt
}

Received 200210 26; accepted 20030228

\begin{abstract}
Fast development of the number of vehicles is closely related not only to large benefit for the public but also to certain undesirable social and economic consequences. Firstly - large numbers of injured and killed people are involved into the accidents.

The target to improve traffic safety situation in Lithuania can be reached only after the detailed evaluation of transport system, environment, traffic participants, road and vehicle.

Taking into consideration the accident situation in Lithuania and its causes the followings priority trends are suggested: The improvement of the coordination of road traffic safety system, the training and education of road users, the explanation of the importance of traffic safety and its propagation, the improvement of traffic conditions. Recommendations and proposals for differentiated criterion of maximum speed limit selection taking into account different factors are provided in the work.
\end{abstract}

Keywords: traffic, safety, transport, accident, prevention, strategies.

\section{Introduction}

Accidents as unhappy events have held man's interest throughout history and mankind has tried both to explain the causes of accidents as well as to combat them and avoid risk. Nowadays we see accidents as events that can be explained and treated in an analytical and systematic way as a result of ongoing interdisciplinary research.

Among the early pioneers in safety and traffic accident research could be mentioned:

R. J. Smeed, an English researcher who showed (in 1949) how road accident fatalities in different countries are related to their population and number of registered motor vehicles. The risk will decrease as the number of motor vehicles per population increases [1];

J. S. Baker, an American researcher pointed out (in 1960) that some chief causes of an accident can be observed in accident investigations but that as a rule there will be no single evident cause of an accidents and systematic analyses are therefore necessary [2];

W. Haddon Jr., an American scientist, set up (in 1970) a framework for categorizing highway safety phenomena., based on three phases. Human, Vehicle and Environment, and also presented a theory on how accidents are related to production and release of energy $[3,4]$.

The "Triple E" for traffic safety improvements has long been used as a strategy, established perhaps as early as 1930s. The three E s stand for:

Engineering, measures enacted in vehicle, road and traffic engineering;
Education, training of drivers and traffic education in schools;

Enforcement, ensuring and imposing obedience to traffic laws and regulations.

However, researchers in psychology point out that behavioral adaptations to safety measures in the transport system must also be considered [5]. According to the theory of Risk Homeostasis, people take risks to reach a variety of goals [6]. The introduction of safety devices (e.g., seat-belt wearing, studded tyres) has led to drivers feeling safer and compensating by driving faster (Risk compensation). The result can be that drivers are causing more injuries to other road users such as back-seat passengers, pedestrians and cyclists [7]. People must be willing to accept risk-reducing countermeasures to achieve positive safety results. This factor may be strengthened by incentives, e.g., a bonus for driving without being at fault in an accident [8].

\section{Theoretical Study}

Accident has been given many definitions, among them an event which happens completely by chance. However, as it has been said, "Accidents don't just happen - accidents are caused". A more adequate definition would be: "An accident is an undesired an unpleasant suddenly occurring event with human and economic losses caused by uncontrolled disturbances in the interaction of components in a system". 
Risk is regarded in every day language as the consequence of an accident. Scientists, however, use risk as an expression of the probability that an accident will happen. In general, the probability of any outcome (e.g. an accident) is equal to the ration of the number of outcomes (accidents and their consequences) to the total number of outcomes (exposure to risks) $R$ :

$$
R=f(p, C),
$$

where $p$-probability; $C$ - consequence of the event [9].

Safety is a question of the political and ethical judg. ment of the "acceptability of risk". A thing is safe if its risks are judged to be "acceptable" [10]. However, the determination of safety must also include an acceptable level of losses in health for each injured person. The ultimate goal - the Zero-Vision - must be to avoid all severe accidents [11].

A list of terms used in accident research and prevention:

Accident - An undesired and unpleasant suddenly occurring event with human and economic losses;

Active safety - qualities and equipment that help road users to avoid an accident, e. g., multilevel interchanges, road lighting, $\mathrm{ABC}$ brakes;

Incident (or near-accident) - a distinct occurrence that can lead to an accident if strenuous actions are not taken within limited time (even within microseconds);

Passive safety - qualities and equipment that reduce the injuries and losses in case of an accident, e. g. breakaway poles, shock-absorbent vehicle construction, air bags, seat belts;

Perceived risk - the emotional feeling of the uncertainty of a possible event or danger;

Risk - the ratio of the number of specific outcomes (accidents and their consequences) to the total number of outcomes (exposure to risks);

Safety - acceptable level of risk; Acceptable losses in health;

Statistical risk - risk calculated from existing data on accidents and exposure, e. g., injured persons per 100000 vehicle $\mathrm{km}$. or - when the exposure is regarded to be a function of the size of the population - as e. g. fatalities per 100000 inhabitants;

Traffic accident prevention - the application of safety principles in vehicle design and inspection, design of new built-up areas and roads, and improvement of existing areas and roads in order to satisfy traffic and environmental demands;

Traffic accident reduction - Remedial measures directed toward reducing accidents of a special type (e. g., drunk driving) or reducing accidents at sites with high numbers of accidents.

\section{Examples of System of Strategies}

A road traffic system can be described as a ManMachine-Environment system with a complexity of fac- tors involved [12]. The basic, momentarily interacting components on the micro level are (Fig 1): the Driver (D) or Road User, the Vehicle (V), and the Road (R). The state of each of these components is of great significance for the successful outcome of the interaction: for the Driver, the driving ability and experience, if he/she is free from or influenced by tiredness, drugs etc. and if he/she is using seat belts: for the Vehicle, the operation standard (brakes, tyres etc.) and the safety standard (shock-absorbent body, ABS brakes, air bags); and for the Road the current design standard, surface friction etc.

Theses three components form a subsystem, here called a DVR unit. Several DVR units in operation together constitute the Traffic Environment, a synthesis of the current traffic conditions with a given set of drivers and vehicles, which can be observed as the number of vehicles, pedestrians and cyclists, of speed variations and generated traffic situations, and the communication between road users (Fig 1). We now extend the micro level to include the meso level, where the Psycho-Social environment of the driver (education, values, family and employment situations, etc.), and the Local Physical Environment (sight and weather conditions, surrounding buildings and landscape, etc.) have a direct or indirect influence on the traffic environment, the road and the vehicle (Fig 2).

An important component on the macro level is often not considered, namely Society itself (Fig 3). The Society with its sociocultural and economic systems, policies, laws and regulations, constitutes the standard of living, education level, public spirit and lifestyles of the population. The societal factors in a traffic safety concept can be observed as car ownership and usage, demand for various means of transport, traffic restrictions, behavior of

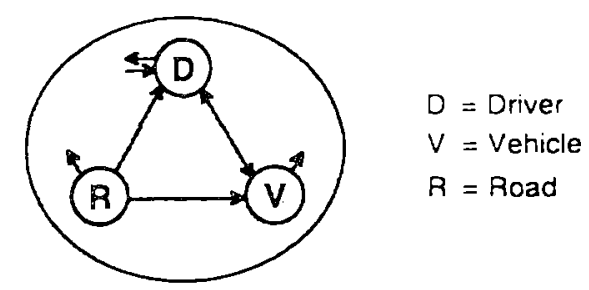

Fig 1. The Micro level

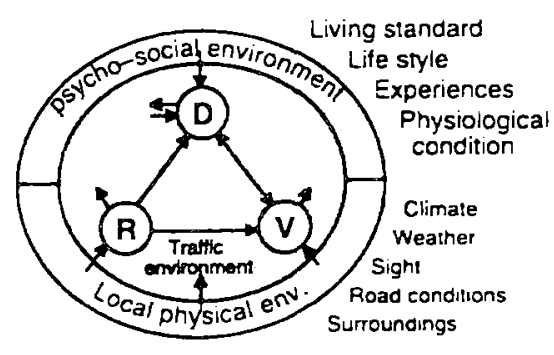

Fig 2. The Meso level 


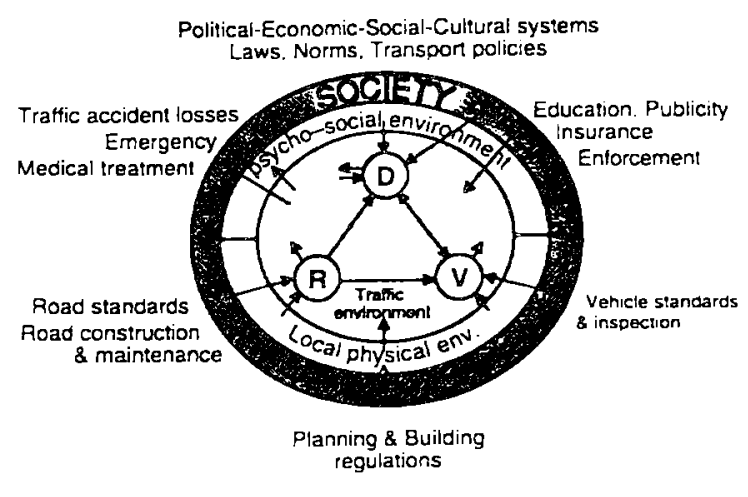

Fig 3. The Macro level

road users, risk-taking, etc. The traffic environment - seen as the "traffic culture" - can be said to mirror the society in question.

This and other similar or more detailed behavioral models can be used to understand and analyze the complex interaction between all the components of a road traffic system. However, the Human must always be regarded as the weakest component.

Haddon has set up a scheme for describing the causes of accidents and directing countermeasures in road safety. He introduces three "Phases" of interactions that lead to the end-results- of road losses in lives and property, namely PreCrash and PostCrash, and three groups of "Factors" involved in each of the three phases of interactions that lead to the end-results of losses, namely Human, Vehicle and equipment, and Environment. By combining the Phases with the Factors a $3 \cdot 3$ - matrix can be constructed for categorizing road losses, countermeasures and program efficacy (Table 1).

The matrix of Haddon can be extended to include more factors. Miller [13] has set up a "Risk/PPR matrix" where the role of different sources of hazards and countermeasures are included in a twin fifteen-cell matrix. The five factors are Human, Vehicle, Infrastructure, Environment and Institutional concerns. Another improvement could be to add two other Phases to PreCrash, Crash, PostCrash, namely PreTrip and Post Trip resulting in a $5 \cdot 5$ - matrix (Table 2).

Haddon states that many ecological phenomena involve "the transfer of energy in such ways and amounts, and at such rapids rates, that inanimate or animate structures are damaged". Accidents can be said to be the result of an overproduction of energy or a misdirected use of it. Ten general strategies for reducing losses were given as follows, here applied for road traffic as a use of mechanical energy (Table 3). Haddon's strategies are more technically oriented than his framework of Phases and Factors, which include human factors.

Injury reduction strategies are proposed by the Trinca Group. A group of eight internationally well-known scientists, the Trinca Group [14, 15], published in 1988 "Reducing Traffic Injury - A Global Challenge". The group
Table 1. Framework for categorizing road accident factors

\begin{tabular}{|l|l|}
\hline Designation & Example \\
\hline $\begin{array}{l}\text { PreCrash - } \\
\text { Human }\end{array}$ & The role of alcohol in crash initiation \\
\hline Crash - Human & $\begin{array}{l}\text { The large resistance of the properly } \\
\text { packaged human body to crash forces }\end{array}$ \\
\hline $\begin{array}{l}\text { PostCrash - } \\
\text { Human }\end{array}$ & Hemorrhaging of damaged people \\
\hline $\begin{array}{l}\text { PreCrash - } \\
\text { Equicle and } \\
\text { Crash - Vehicle } \\
\text { and Equipment }\end{array}$ & $\begin{array}{l}\text { Tire blowouts and other mechanical } \\
\text { failures } \\
\text { exterior structures to damage; the } \\
\text { such a way that they are driven } \\
\text { backward in frontal crashes and } \\
\text { impale or crush driver's chests }\end{array}$ \\
\hline $\begin{array}{l}\text { PostCrash } \\
\text { Vehicle }\end{array}$ & $\begin{array}{l}\text { Difficulty and cost of vehicle-damage } \\
\text { repair }\end{array}$ \\
\hline $\begin{array}{l}\text { PreCrash- } \\
\text { Environment }\end{array}$ & $\begin{array}{l}\text { Low coefficients of friction on road } \\
\text { surfaces, inadequate signs and signals, } \\
\text { ineffective police control of speeding }\end{array}$ \\
\hline $\begin{array}{l}\text { Erash - } \\
\text { Environment }\end{array}$ & $\begin{array}{l}\text { Trees, ditches, unyielding poles, } \\
\text { bridges and other solid structures } \\
\text { without interposed guard rails, soft } \\
\text { shoulders along roadsides }\end{array}$ \\
\hline $\begin{array}{l}\text { Inadequate provision of emergency } \\
\text { telephones, inadequate planning and } \\
\text { operation of emergency and other } \\
\text { social response systems }\end{array}$ \\
\hline
\end{tabular}

Table 2. Extension of Haddon's framework according to the interaction model in Fig 1.

\begin{tabular}{|l|c|c|c|c|c|}
\hline \multicolumn{1}{|c|}{ PHASES } & Society & Road & Vehicle & Environment & Human \\
\hline PreTrip & S-1 & R-1 & V-1 & E-1 & H-1 \\
\hline PreCrash & S-2 & R-2 & V-2 & E-2 & H-2 \\
\hline Crash & S-3 & R-3 & V-3 & E-3 & H-3 \\
\hline PostCrash & S-4 & R-4 & V-4 & E-4 & H-4 \\
\hline PostTrip & S-5 & R-5 & V-5 & E-5 & H-5 \\
\hline
\end{tabular}

points out that road accidents pose a great health problem and estimated that, worldwide, some 15 million persons are injured every year and that half a million persons die. Five categories of strategies are proposed, namely:

(1) Exposure Control, accomplished by shaping public policy such that the amount of travel is reduced, or transferred to safer forms of travel from less safe ones, including legislation, fiscal policies and licensing procedures;

(2) Crash Prevention, refers to Road Engineering, i.e., the provision of adequate road systems with design, construction and maintenance standards directed to safety, to Vehicle Engineering, i.e. design features and in-service conditions of vehicles, and to Computer Control of 
Table 3. Strategies for reducing losses

\begin{tabular}{|c|c|}
\hline $\begin{array}{l}\text { Strategy according to } \\
\text { Haddon }\end{array}$ & $\begin{array}{l}\text { Examples, applied to road } \\
\text { traffic }\end{array}$ \\
\hline $\begin{array}{l}\text { 1. Prevent the marshalling } \\
\text { of a form of energy }\end{array}$ & Don't start any cars \\
\hline $\begin{array}{l}\text { 2. Reduce the amount of } \\
\text { energy marshalled }\end{array}$ & $\begin{array}{l}\text { Reduce engine } \\
\text { powerLower the speed of } \\
\text { vehicles }\end{array}$ \\
\hline $\begin{array}{l}\text { 3. Prevent release of the } \\
\text { energy }\end{array}$ & $\begin{array}{l}\text { Train drivers to avoid } \\
\text { skiddingInstall ABS-brakes }\end{array}$ \\
\hline $\begin{array}{l}\text { 4. Modify the rate or } \\
\text { spatial distribution of } \\
\text { release of the energy from } \\
\text { its source }\end{array}$ & $\begin{array}{l}\text { Use seat beltsEnergy- } \\
\text { absorbing vehicle design }\end{array}$ \\
\hline $\begin{array}{l}\text { 5. Separate, in space or } \\
\text { time the energy being } \\
\text { released from the } \\
\text { susceptible structure }\end{array}$ & $\begin{array}{l}\text { Separate physically by } \\
\text { constructing multilevel } \\
\text { interchanges. Separate } \\
\text { vehicles from } \\
\text { pedestrians/cyclists by } \\
\text { walkways, bikeways }\end{array}$ \\
\hline $\begin{array}{l}\text { 6. Separate by interposition } \\
\text { of a material barner }\end{array}$ & $\begin{array}{l}\text { Install median, lateral road } \\
\text { barnersInstall air bags in } \\
\text { vehiclesUse helmets when } \\
\text { driving motorcycles }\end{array}$ \\
\hline $\begin{array}{l}\text { 7. Modify appropriately the } \\
\text { contact surface, subsurface, } \\
\text { or basic structure }\end{array}$ & $\begin{array}{l}\text { Design shock-absorbent } \\
\text { vehicles }\end{array}$ \\
\hline $\begin{array}{l}\text { 8. Strengthen the structure, } \\
\text { living or nonliving, that } \\
\text { might be damaged by the } \\
\text { energy transfer }\end{array}$ & $\begin{array}{l}\text { Prevent osteoporosis. Treat } \\
\text { hemophilia to minimize the } \\
\text { risk of fracture or } \\
\text { uncontrollable bleeding }\end{array}$ \\
\hline $\begin{array}{l}\text { 9. Detect rapidly and } \\
\text { evaluate the damage that } \\
\text { has occurred or is } \\
\text { occurring, and counter its } \\
\text { continuation and extension }\end{array}$ & $\begin{array}{l}\text { Install and use of SOS } \\
\text { alarmsProvide emergency } \\
\text { medical care and transport }\end{array}$ \\
\hline 10. Repair and rehabilitate & $\begin{array}{l}\text { Give appropriate } \\
\text { intermediate and long-term } \\
\text { medical care. Provide } \\
\text { rehabilitative measures to } \\
\text { help injured persons to } \\
\text { return to a normal } \\
\text { life. Repair damaged } \\
\text { vehicles }\end{array}$ \\
\hline
\end{tabular}

traffic and on-board displays to give a driver information on traffic situations, warnings, etc.;

(3) Behaviour Modification, including educational programs, legal encouragement of correct behaviour, etc;

(4) Injury Control, including crash protective measures in vehicle design (crash energy management) and in the road environment by the elimination of poles, trees, etc., or use of break-away installations;

(5) Post-Injury Management, including efficient treatment and rehabilitation services in case of traffic crashes which cannot be entirely prevented.

The application of these strategies is discussed for both highly motorized countries and for motorizing coun- tries, and proposals are made how to organize traffic safety activities on both national and international levels.

\section{Conclusions}

Contributors to safety strategies have pointed out that only a systematic and consistent approach in comprehensive programs can reduce the losses of lives and property in road traffic. Generally, these approaches can be summarized in three basic actions:

- Traffic Exposure Control - the establishment of policies and regulations that reduce transport demand (through organization of the urban fabric, the institutional and company structure or the daily life of individuals), transfer of a given transport need to safer forms of transport or avoidance of transport using telecommunication instead;

- Accident Risk Control - provision of technical measures in Vehicle Road Traffic and Computer engineering directed to eliminate, reduce or detect risks and incidents that can generate accidents (Active safety), and measures that influence road users to behave correctly;

- Injury Control - installing protective measures in vehicle design, and softening the road environment such that the consequences of a traffic crash are eliminated or strongly reduced (Passive safety), and efficient rescue service, medical treatment and rehabilitation of persons injured in accidents that cannot be prevented through all measures that have been taken prior to or under the crash situation.

The efficacy of the application of these safety actions for specific population can be measured as a volume of traffic injures $\mathrm{N}$ according to the following formula [16]:

$$
N=E \cdot A \cdot I,
$$

where $E$-a measure of traffic exposure; $A$ - the accident risk, given as number if accidents related to the exposure unit; $I$ - the injury rate per accident.

The safety audit is a procedure for safety quality control of new road projects or reconstructions of existing roads [17]. Its purpose is to systematically check traffic safety issues during planning and construction of the road infrastructure in order to:

1. Prevent the construction that can generate accidents risks;

2. Identify and suggest alternatives and modifications in order to gain safety benefits.

\section{References}

1. Smeed, R. J. Some statistical aspects of road safety research. Journal of the Royal Statistical Society, Series A. 112, 1949.

2. Baker, J. S. Experimental case studies of traffic accidents. A general discussion of procedures and conclusions. NorthWestern University. Evanstone, 1960. 
3. Haddon, W. Jr. A Logical Framework for Categorizing Highway Safety Phenomena and Activity. The 10th Int. Study Week in Traffic and Safety Engineering. Rotterdam, 1970.

4. Haddon, W. Jr. On the Escape of Tigers: An Ecologic Note. Technology Review, May 1970.

5. OECD. Behavioural adaptations to changes in the road transport system. Road Research. Paris, 1990.

6. Wilde, G. The theory of risk homeostasis: implications for safety and health. Risk Analysis, No 2, 1982.

7. Adams, J. Risk and Freedom: The Record of Road Safety Regulation. Transport Publishing Projects. Cardiff, 1985.

8. Trimpop, M.; Wilde, G. J. S. Challenges to Accident Prevention. The issue of risk compensation. STYX Publications. Groningen, 1994, Hovden J. Evaluation of accident risk. TAPIR. Trondheim, 1979.

9. Hovden, J. Evaluation of accident risk. TAPIR. Trondheim, 1979.

10. Lowrance, W. W. Of Acceptable Risk. Science and the Determination of Safety. Wiliam Kaufmann Inc. Los Altos, 1976.
11. Swedish Road Administration. The Zero-Vision. Borlange, 1996.

12. Sadauskas, V. Car passive safety study. Engineering. Transport Engineering (Transportas), Vol, 2000, XV t., No 1, p. $41-50$ (in Lithuanian).

13. Miller, C. H. Crash Avoidance Parameters. 30th Annual Proceedings. American Association for Automotive. Montreal, 1986.

14. Trinca, G. W. et. al. Reducing Traffic Injury - A Global Challenge. Royal Australasian College of Surgeons. Melbourne, 1988.

15. Gunarson, S. O. Traffic Accident Prevention \& Reduction review. LATSS Research, Vol 20, No 2, 1996.

16. Nordic traffic safety board. Information System for Traffic Safety Actions. Report No 30. Linkoping, 1981.

17 Proctor, S; Becher, M. The use of road safety audits in Great Britain. Traffic Engineering and Control, London, 1993. 